\title{
Rational choice in procuring benefits of geothermal energy management in Lahendong, North Sulawesi, Indonesia
}

\author{
Welky Karauwan ${ }^{1}$, Paulus Kindangen ${ }^{2}$, Kliwon Hidayat ${ }^{3}$, Maryunani ${ }^{4}$. \\ ${ }^{I}$ Graduate Scholl of Environmental Studies, University of Brawijaya, Jl. Veteran 65145, Malang, East Java \\ Indonesia and Universitas Kristen Indonesia Tomohon, Jl. Raya Kuranga Talete II Tomohon, North Sulawesi, \\ Indonesia \\ ${ }^{2}$ Faculty of Economic, Sam Ratulangi University, Bahu Campus, Manado 95115, North Sulawesi, Indonesia \\ ${ }^{3}$ Faculty of Agriculture, University of Brawijaya Jl. Veteran 65145, Malang, East Java, Indonesia \\ ${ }^{4}$ Faculty of Economic, University of Brawijaya Jl. Veteran 65145, Malang, East Java, Indonesia
}

\begin{abstract}
This study aimed at understanding the concepts in making rational choices in procuring benefits of geothermal energy management in Lahendong, North Sulawesi, Indonesia. Data was collected through focus group discussion. The results of the study showed that Lahendong had become an action arena, meaning that the management of the geothermal energy reconciled many interests as well as caused conflicts of interests among stakeholders. Those considered as stakeholders consisted of the government, the management staff, and the local people. Each party possessed their interests, which were influenced by the values and the culture they belonged to, as well as situation and condition. The government's goal is to provide public needs for the welfare of the society. The company intends at gaining as much profit as possible from the products it sells, which is the geothermal energy for power plants. The company will not achieve the Break Even Point in 25-30 years, and from the perspective of business, it has to stop its business activity. The company survives merely on the crosssubsidy by PT Pertamina. The local people aim at procuring benefits through their externality by means of profit-oriented behavior, satisfaction-oriented behavior, and the combination of profit-and-satisfaction-oriented behavior. All these actors use the direct and indirect actions, positive and negative ways, as well as the legal and illegal methods.
\end{abstract}

Keywords: rational choices, geothermal energy, sustainable development

\section{INTRODUCTION}

The development process that takes into account the balance among the economy, social, and environmental aspects has become such a global crucial issue these days. The elements of ecosphere, sociosphere, and economy must be considered and must be put into interaction, not only in mechanistic atomistic manners through separated approach, but also in direct and complement ways. Only in such these ways will the development process happen successfully and sustainably in the long-term plan, where the environment system is in balance and carrying capacity, assimilative capacity, as well as harmony diversity can be maintained harmoniously. All of these are the foundation for sustainable development as the basic reference in managing the environment, one of which is in the management of natural resources for the good of our lives [1] [2].

In the management of natural resources for the good of human beings and development goals, the most problematic area is the fact that the benefits gained and the cost paid is imbalance, leading into social cost problems [3]. That is also the dilemma faced in the management of the geothermal energy, in which it brings both the positive externalities and the negative ones. There may also tendency in which the benefits gained are a lot less than the social cost incurred.

There is a geothermal energy management project in Lahendong, North Sulawesi, Indonesia. PT Geothermal Energy Area Lahendong (PT PGEA Lahendong) runs this project in Tomohon and Minahasa. The project is important as it aims at providing national-scale electricity to replace the scarcer fossil fuel energy. As part of the national-scale electricity supply program, this project has been able to provide the electrical energy for the whole province of North Sulawesi, Gorontalo, and Central Sulawesi. In addition to electrical energy, as its main product, the plant also produces waste in form of steam heat that can be used in farming activities and for drying the agricultural products. The plant also creates employment for the local people, helps building public infrastructure such as road and public buildings [4] [5] [6].

The project of geothermal energy management in Lahendong is expected to bring advantages for all and to help reconcile the zone as to maintain the balance of the environment system, the social system, and the economy. However, the project also causes negative impacts to the society. Degradation in the quality of the environment, conflict of interests among stakeholders, and other disputes has made this project appeared troublesome and ill favored. 
The stakeholders of any development project, including the geothermal energy management project in Lahendong, are the government, the management staff, and the local people. The government as the policy maker concerns on improving the social welfare of the society, the company focuses on making profit, while the local people aim at procuring benefits form the positive externality [7].

Every stakeholder becomes the actor having their own rational choices related to their purposes and ways to achieve their goals. Each party has their capacity to decide rationally the alternatives they take. In deciding their choices, these actors cannot be separated from their personal interests and their basic characteristics as human beings, which is selfish, rational, and puts their personal interest as their upmost priority [8]. These are the factors causing so much problems in the management of the geothermal energy in Lahendong - the conflicts of interests among the stakeholders. This study aimed at exploring the perception of the local community toward the geothermal energy project and analyzing the rational choices appearing in relation to the existence of the geothermal energy project in Lahendong, North Sulawesi, Indonesia.

\subsection{Study Site}

\section{METHODOLOGY}

This study was conducted at the geothermal energy management site, in Lahendong, especially in SubDistrict South Tomohon, Sonder, and Remboken. Data was collected from several villages in South Tomohon, namely Lahendong, Pangolombian, and Tondangow. In Sonder, data was collected from Leilem Dua Village. In Remboken, data was collected from Kasuratan Village. Administratively, the study site included Tomohon and Minahasa Regency. The geographical position of the study site is illustrated in Figure 1.

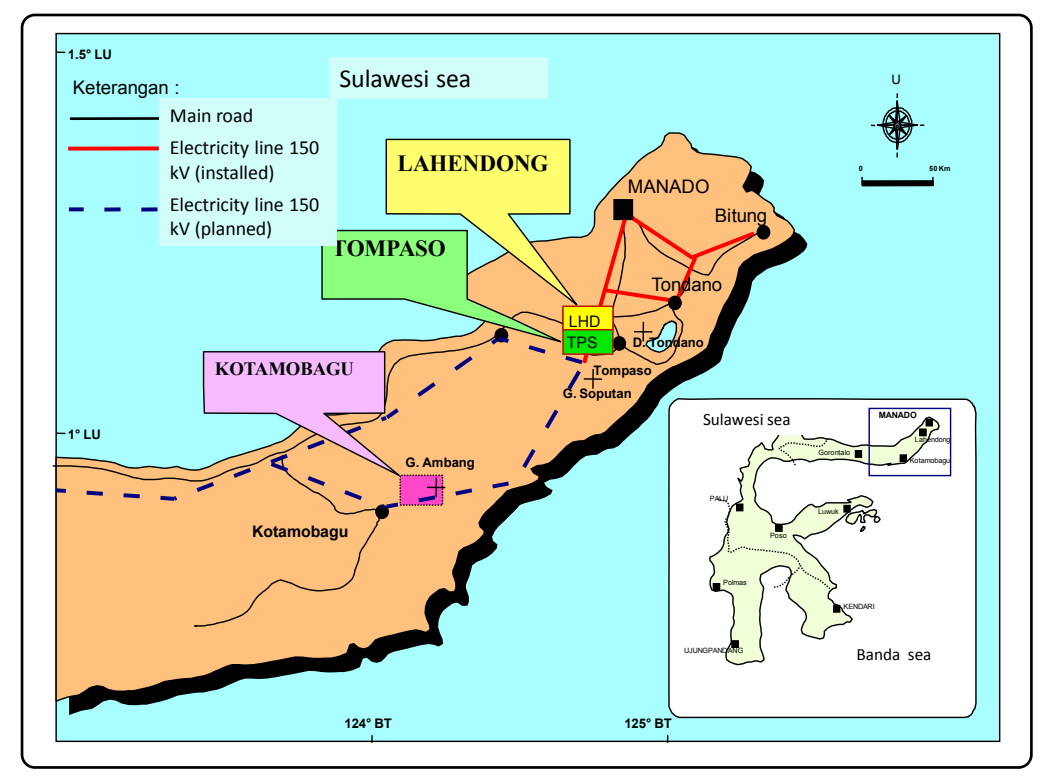

Figure 1: Geographical Position of Geothermal Energy Site Project in Lahendong (Source: PGE Area Lahendong)

\subsection{Methods}

The study was conducted using a descriptive analytical method. The study took place in July 2012 until June 2013. The study involved 100 adult local people as the participants without any consideration regarding to sex, educational background, social status, or job. This was done in relation with the different impacts each person experienced due to the existence of the Lahendong geothermal energy project. As many as 20 people were chosen from each village through a quota sampling. These participants were then grouped into 10 groups for the Focus group discussion, in which the topic of the discussion was "the rational choices of the local people in procuring benefits of geothermal energy management in Lahendong". There were two groups in each village; every group consisted of ten participants. The information is summarized in Table 1.

Table 1. Participants in $F G D$

\begin{tabular}{llcc}
\hline No. & Village & $F G D$ & The Number of Participants \\
\hline 1 & Lahendong & I & 10 \\
& & II & 10 \\
2 & Pangolombian & III & 10 \\
& & IV & 10
\end{tabular}




$\begin{array}{cccc}3 & \text { Tondangow } & \text { V } & 10 \\ 4 & & \text { VI } & 10 \\ 4 & \text { Leilem Dua } & \text { VII } & 10 \\ & & \text { VIII } & 10 \\ & \text { Kasuratan } & \text { IX } & 10 \\ & & \text { X } & 10\end{array}$

FGD was done to collect primary data; each FGD lasted for approximately two hours, and was done either in the participants' house or in the village meeting hall. The other data came from the documentation done at the office of PT Pertamina Geothermal Energy Area Lahendong, the village office, and other government institutions. The data collected was analyzed using the descriptive analysis method. The process of data analyses took place throughout the study.

\section{RESULT AND DISCUSSION 3.1. The Perceptions of the Local People toward the Project of Geothermal Energy Management in Lahendong}

The project of geothermal energy management in Lahendong is part of the project in the management of geothermal energy for power plants under the national energy project of Indonesia. This project was set up after a series of feasibility study done by the (1) Asian Development Bank, 1973-1978, "Appraisal Study of Power Alternatives in Minahasa." Exploration Survey by Drilling 3 Exploration Wells, (2) Detailed Exploration Survey by Drilling 7 more wells, 1982-1987, and (3) Feasibility Study and Utilization of Binary System With BPPT, 1989-1992 [9].

The project at Lahendong is part of the National Energy Policy, which is written in the blueprint of the National Energy Management 2010 - 2025. According to the policy, geothermal energy takes $6.3 \%$ in the national energy mix in 2025. The geothermal energy management is considered a strategic project since it contributes to the compliance of the national electrical energy needs, and the project itself is now able to meet the needs of electrical energy for North Sulawesi, Gorontalo, and Central Sulawesi. According to the report by PT PGEA Lahendong, the geothermal power plant in Lahendong is able to supply as much as $60 \mathrm{Mw}$ or $44 \%$ from the total $136.35 \mathrm{Mw}$ electricity needs in North Sulawesi, Gorontalo, and Central Sulawesi. In addition, this project also aims at supporting the national economy growth and benefits for stakeholders [9].

PT PGEA itself realizes that there are rights of the local people to consider and to meet. Thus, the company initiates partnership and community development programs, as well as the corporate social responsibility programs. This is in accordance with Indonesia Law Number 19 Year 2003 on BUMN, Indonesia Law Number 9 Year 1955 on Small Scale Business, and PER05/MBU/2007 on Partnership and Community Development Programs.

The local people around the site plan see the project as a government program aimed at providing energy for power plants; thus, the project must be supported for it brings such great benefits for the lives of the people. The project opens up employment for the local people, both as freelancers or as full-timers, and creates other forms of advantages, both from the backward linkages and the forward linkages.

The availability of roads, buildings, school buildings have brought such great benefits for the lives of the people. Other forms of business, such as food stalls and public transportation, also come into existence due to the project installation. The local people believe that the project of geothermal energy management at Lahendong has accelerated economy development and social improvement for them. This situation similar with some projects in developing countries [10]. Nevertheless, the people also state that the project has brought significant changes. Farming activities and natural biodiversity have been replaced with machines and production equipment. Local wisdom and high solidarity among the local people have turned into individualistic-materialistic characters. The researcher has seen this project as a triggering factor for conflict of interests among stakeholders. The conflict deals with the effort to dominate and control the benefits of the project. This conflict is followed with a series of rational choices from each stakeholder of the project. Those stakeholders are the government, the management staff, and the local people.

\subsection{The Actors, Their Goals, and Their Way of Achieving Goals a. The Actors behind the Rational Choices}

The actors of the rational choices in the project of geothermal energy management in Lahendong consist of three parties, namely the government, the management staff, and the local people. These three parties play such important role in the project of geothermal energy management in Lahendong.

The government consists of the central government, the provincial government, and the local or municipal government. The companies having the authority to run and manage the project are PT Geothermal Energy Area Lahendong and PT Pertamina. The government establishes the regulations on industry operational systems as to guarantee that the project is conforming to the national goals [11]. 
The local people refer to the people living in the areas around the site of the geothermal energy management project, classified by the social status as the lower-class people, middle-class people, and upperclass middle. The lower class includes farmers, labors, and informal sector workers. The middle class consists of civil servants, merchants, and those working in private sectors. The upper class refers to businesspersons and government officials. This stratification is similar to those found in developing countries. The lower and middle classes are dominant, and have low to enough educational background and economy [11].

\title{
b. The Goals of the Rational Choices
}

The goal of the government related to the benefits of the project is to improve the social welfare of the people by providing the electricity needed. The availability of electricity will accelerate economy growth, both macro and micro sectors and will also create multiplier-effect of economy. In addition, the project is also a source of revenue for the central government, the provincial government, and the local or municipal government.

Indonesia Law number 27 Year 2003 on Geothermal Energy, Chapter 30 regulates the state revenue from the management of the geothermal energy that may come in forms of taxes and non-taxes. Revenue from taxes consists of the tax itself, import duty and excise duty and other levies on imports, local taxes and levies. Non-tax revenue comes from levies in forms of fixed fees and production fees and other charges in accordance with the state laws and regulations, as well as bonuses.

The revenue in form of taxes is divided based on the state laws and regulations. Non-tax revenue comes from levies in forms of fixed fees and production fees are divided between the central government $(20 \%)$ and the local government $(80 \%)$. The $80 \%$ revenue accepted by the local government is divided between the three levels of government, that is $16 \%$ for the provincial government, $32 \%$ for the municipal government, and the other $32 \%$ is for other municipalities in that province. The management staff aims at gaining profits form the output, as well as warranting wealth for the company's workers.

The local people aim at procuring benefits from their positive externality, which can be categorized as direct use value and indirect use value. The direct use value comes in forms of (1) the use of steam waste for farming, drying up harvested farming products, as well as room heating and cooling; (2) the new employment; and (3) the use of roads, buildings, and other infrastructure. The indirect use value is the availability of the electricity. The results of the FGD show that the geothermal energy management has reduced and even cut power outage - it used to happen twice a week, two until three hours in each outage, and yet nowadays it only happens under very special circumstance, such as technical error.

The results of FGD on the ten groups of the local people show that they tended to choose three categories of purposes, namely (1) profit oriented, (2) satisfaction oriented, and (3) the combination of profit and satisfaction or utility oriented, as explained in Table 2.

Table 2. The Categories of Purposes per Village

\begin{tabular}{lcccc}
\hline Kelurahan/Desa & Group & Profit & Satisfaction & $\begin{array}{c}\text { Combination } \\
\text { (utility) }\end{array}$ \\
\hline Lahendong & I & D & ND & VD \\
& II & ND & D & VD \\
Pangolombian & III & D & ND & VD \\
& IV & ND & ND & VD \\
Tondangow & V & ND & D & VD \\
& VI & D & ND & D \\
Kasuratan & VII & D & VD & ND \\
& VII & D & VD & ND \\
LeilemDua & IX & VD & ND & D \\
& X & VD & D & ND
\end{tabular}

\author{
Source: Research Results, 2012 \\ Note: \\ VD : Very Dominant \\ D : Dominant \\ ND : Not Dominant
}

This data shows that the people in Lahendong, Pangolombian, and Tondangow tend to be utilitarianism. The people in Kasuratan tend to be satisfactionism, while those in Leilem tend to be profit economism. These tendencies are caused by the social and economy values believed by those people rooted in 
their local culture and customs. These findings are strengthened by the theory of rational choices that emphasize goals. Huber shows that rational choices are closely related to purposive behavior analysis. Purposive behavior becomes such critical element in rational choices. The characteristic of the rational choice theory sees choices as a process to optimize goals. Heckathorn states that making choices is a rational action. The theory on rational choices really emphasizes on the principle of "efficiency" in pursuing goals of any actions [12].

\section{c. Means}

\section{c.1. The Government}

The government achieves their goal through a political process by means of methods and instruments of economy (public choice). The geothermal energy as power plant energy belongs to the public and is managed to fulfill the public needs. Through laws and regulations, the government establishes their policy. The main benefit the government pursues is the increase in the social welfare of the citizens. By granting permission to the management team, the government is on their way to fulfill the need of the citizens, that is the electricity, and to accelerate both macro and micro economy development [11].

The officials, the bureaucrats, and the legislative run the policy. In such this sense, the government is called as a corporate actor, since many parties not individuals play their role. On the other hand, these corporate actors consist of individuals having the tendency to misuse their position as to maximize personal benefits, interests, and power. Rent-seeking then becomes the next problem regarding this role as a corporate actor. Rentseeking is an attempt to obtain economic rent, (i.e., the portion of income paid to a factor of production in excess of that which is needed to keep it employed in its current use), by manipulating the social or political environment in which economic activities occur, rather than by creating new wealth. Rent-seeking practices include bribery, corruption, smuggling, and black market [13].

In relation to rent-seeking tendency, some practices have been revealed to happen in Lahendong. The first was the financing by the management staff to the legislative members doing working visit to other areas. This information was based on the conversation between a legislative member with ten fired outsourcing workers. The second was when a relative of the local authority won a tender, and the local people assumed that there was such political approach in the process. The third was the manipulation in the data of steam-waste utilization by Non Governmental Organization, in which it was said to be used by 7,000 farmers but in reality it was not. A worker of PT PGEA Lahendong involving in FGD I stated that the business (the steam-waste utilization) was just a game played to get the fund from the central government. This business seems legal and is hard to be subjected to crime, as this kind of business is founded under the name of a family not a government official. This kind of practice is negative in nature, and although there is not any legal sanction, it is still hard to stop the social sanction. The local people believe that political forces have played certain roles in the management of the geothermal energy and everything related to it. This situation similar with some project development where people inviting to involve in such programs [15].

\section{c.2. Management Team}

The management team here refers PT PGEA Lahendong. The company gets profit from selling the geothermal energy to National Electricity Company (Perusahaan Listrik Negara, PLN), a state company in charge of managing national use of electricity. The price was IDR 185 per $\mathrm{KwH}$, and then increased into IDR 215 per $\mathrm{KwH}$ in 2012. With such this price, the company will not get into the break-even point until 25 to 30 years later [9]. This is due to the monopsony system, in which PLN as the single buyer decides the price and PT PGEA Lahendong has such low bargaining power.

As a company running a business with business principles, thus the rational choice for PT PGEA Lahendong is to shut-down the company. Theoretically and pragmatically, the purpose of any companies is to get profit, as well as to maintain efficiency and the growth of the business. The company stands still until the present time, and this is actually a rejection to both the theory and the practice. This is irrational and is impossible to continue. Therefore, the management of PT PGEA Lahendong states that they still try to get some profit. The researcher believes that there are rational choices behind this present situation at PT PGEA Lahendong. Throughout the study, some information is collected. First, this company is part of PT Pertamina, and as such, PT PGEA Lahendong gets the cross-subsidy from PT Pertamina. Second, PT PLN as the buyer also uses other forms of energy, such as the diesel fuel, sold by PT Pertamina; thus, it means that the geothermal energy from PT PGEA Lahendong is simply a substitute for the diesel fuel and any other forms of fuel bought from PT Pertamina. Third, the policy states that geothermal energy is a substitute for fossil fuel, which has become scarcer these days, and the government is doing a backup through PT Pertamina [9].

\section{c.3. The Local People}

The local people gain the benefits through their externality (the positive impacts). To bear in mind, the main purpose of the company is to provide the geothermal energy, not simply to bring benefits to the local 
people - thus, the local people are simply as beneficiaries. The results of the ten FGD show only the local people having strong relationship and negotiation power with the company as to get direct use value. The local people having no strong relationship and negotiation power with the company are the dependent ones. They depend on some agents, such as their family, relatives, company, organization, government, network, or community leaders, to get the benefits of the geothermal energy management. The dependent groups consist of the elderly people and those having insufficient social capital.

The existence of agents brings both the negative and positive consequences. These agents can increase and decrease the cost of the transaction. Agents having good morale and ethics can help the weak to gain benefits without any cost or with such low cost. On the other hand, agents with such low morale and ethics will only make cost higher for the local people.

In the management of the geothermal energy, these agents appear as broker, both in forms of formal broker and informal or shadow broker. The local people around the site acknowledge the formal broker as vendors. Vendors come in forms such as the workforce providers (outsourcing) for PT PGEA Lahendong, companies providing supplementary materials, etc. The researcher calls the informal brokers as shadow brokers. From the FGD, there seems to be objection from the local people related to the fact that most of the main staff is newcomer, not the local people.

In the theory related to policy on industry, one of the theory states the importance of provision of workforce and employment for local people. In term of materials to support the operation of the industry, priority must be given to local materials found nearby. Thus, there must be consideration in terms of job provision and local employees' development [15].

In addition to rent seeking and broker, a free-riders phenomenon also occurs. A free rider in economics refers to someone who benefits from resources, goods, or services without paying for the cost of the benefit [16]. From the results of FGD III, IV, V, and VI, it can be concluded that free-riders phenomenon does takes place. First, some people intentionally inflated their plants as to get more compensation when they heard that the geothermal energy management project would be started. Some people planted their never-cultivated land with some plants as to get more compensation. Third, there were also people borrowed some money to build permanent in such a short time just to get more compensation for the fake house they built. These all represents the free-rider practices, as the doers had no real contribution to the project.

\subsection{Factors Affecting Rational Choices}

There are factors affecting the action arena, namely physical world, community attribute, and rule-inuse [17] [18]. These factors affect the government, the management staff, and the local people in the management of the geothermal energy in Lahendong. The political, law, and policy factors influence the government nationally and locally, whereas the management staff is influenced by the condition of global, national, and local business condition.

\section{a. Values}

The values believed by the local people around the site of geothermal energy management in Lahendong are rooted in the culture of Minahasa, especially the Tombulu, Tontemboan, and Tolour sub-ethnics; and these values affect the ways the local people in achieving their goals, that is procuring benefits from the geothermal energy management project. By categorizing the information collected during the ten FGD, the values dominating individual behavior of the local people around Lahendong site could be revealed.

The Tombulu sub-ethnic consists of hardworking people. They have high spirit of cooperation. Thus, work in teams in cultivating their land is dominated by the local wisdom of "mapalus". In "mapalus", being disciplined, being responsible, manners, and local wisdom is instilled. However, these people are also lavish. They like to gather and the gathering always costs a huge amount of money for food and beverages. Celebration such as wedding ceremony, birthday, and even funeral normally costs a lot.

The Tolour sub-ethnic is totally social-oriented. They put higher value of dignity and self-esteem, more than they value their belongings, even though they are not ignorant to economy values. They truly appreciate the rights of others. They are tough and hardworking when it comes to their economy.

The Tontemboan sub-ethnic values treasures so much. They are workaholic and thrifty. They appreciate the things they get from the job they do. Different from the Tolour sub-ethnic, Tontemboan subethnic is economic oriented. Rational actions dominate their daily lives.

Parsons' theory is still very relevant to this study. Parsons explains that subjective decision making by an actor reflects the partial results of many forms of pressure, both normative and situational [19].

\section{b. Situation and Condition}

Safe and secure situation offers flexibility to the society to gain benefits as their goals [20]. The results of the FGD show that the existence of the geothermal energy management project has made the local people feel 
anxious. They are worried about the risks of the project. The local people seem to mistrust the company and their employees, since many of the employees choose to stay or rent houses outside the Ring I villages. Thus, the local people insisted through the FGD that the employees of PT PGEA Lahendong stay in their village as to assure the local people that their village is in good condition and is not threatened in any ways and by any means.

The physical, social, and economy condition affects the ways people procure the benefits. The condition of the three villages in Tomohon (Lahendong, Pangolombian, and Tondangow) is relatively similar. These villages are dominated with farms planted with horticulture plants (Data processed from each village, 2012; FGD I - VI, 2012). The local people appreciate cooperation and keep that as one of the local wisdoms. In Leilem village, in District Sonder, Minahasanese was dominated by clove farmer, but most of them also work in furniture industry. As many as $80 \%$ of the villagers are involved in the production of furniture, either as the business owners, carpenters, skillful workers, or unskilled workers. Kasuratan village, in District Remboken, local people are working as peasant with cloves, coffee, and other monthly plants become the main agricultural product. Because the road infrastructure is not good enough, the people still live in a more traditional way. However, the people are tough and resilient. The existence of the geothermal energy management project opens up more access for them as the roads are getting better, wider, and more accessible. They can now sell their products to other villages, taking them on their motor vehicles (FGD VII and VII).

From the study, an empirical model of the rational choice of the local people living around the site project of geothermal energy management in Lahendong can be illustrated (Figure 3).

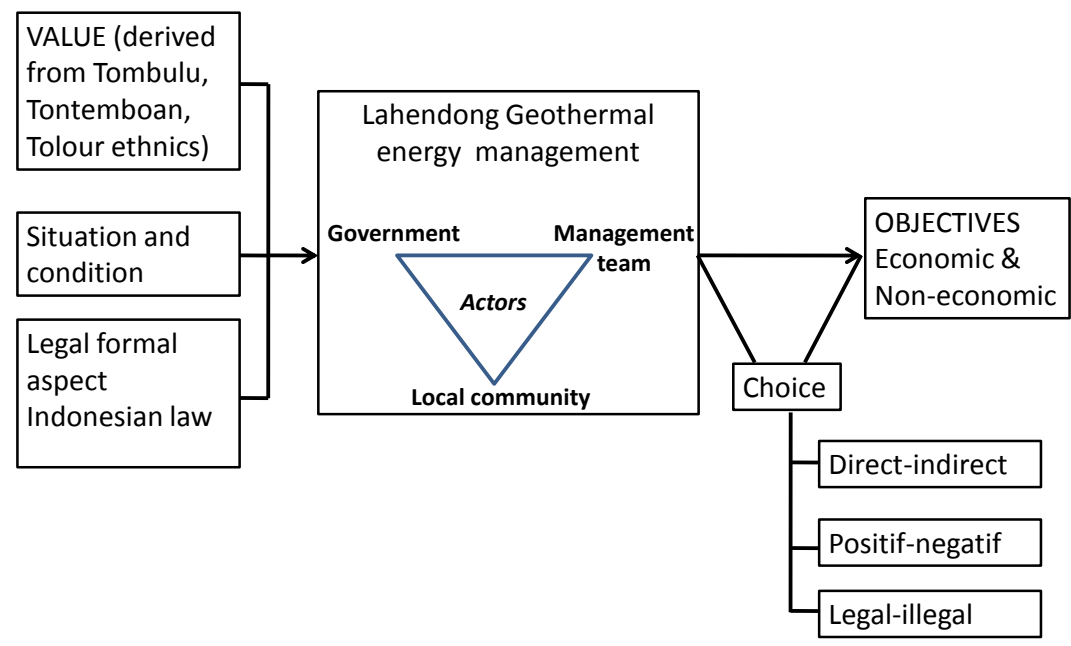

Figure 3: The Empirical Model of the Rational Choice of the Local People Living around the Site Project of Geothermal Energy Management in Lahendong

\section{CONCLUSION}

Geothermal energy belongs to the public and is having such crucial role in the fulfillment of national electricity for the whole citizens of the country. The geothermal energy management project in Lahendong has brought so many benefits as well as created conflicts of interests. The government under certain policy initiated the project in order to provide the public needs. However, in its implementation, there are individuals exercising their own benefits, seeking their own advantages over the project (rent seeking). The local people as beneficiaries gain the benefits through their externality (positive impacts) on the geothermal energy management project in Lahendong. The actors of the project have their own orientation, and their orientation can be classified as profit oriented, satisfaction oriented, and the utility oriented. These people gain the direct use value and indirect use value, get the positive and negative impacts, and exercise both the legal and illegal ways.

The existence of brokers brings both positive and negative impacts, which are to decrease or to increase the cost of the transaction. Brokers come in forms of formal brokers and informal or shadow brokers. In addition to rent seeking and broker, a free-riders phenomenon also occurs. This phenomenon comes in some forms. First, some people intentionally inflated their plants as to get more compensation when they heard that the geothermal energy management project would be started. Some people planted their never-cultivated land with some plants as to get more compensation. Third, there were also people borrowed some money to build permanent in such a short time just to get more compensation for the fake house they built. These all represents the free-rider practices, as the doers had no real contribution to the project. In order to achieve their goals, these actors 
decide the ways or actions they take, and these are influenced by the values rooting in their culture, that is the sub-ethnic culture of Tombulu, Tolour, and Tontemboan as well as situation and condition, which can both become the supporting and the hindering factors.

\section{Acknowledgements}

The authors would like to acknowledge Rector of University of Brawijaya, Director of Graduate Scholl, University of Brawijaya and Directorate General of Higher Education, Ministry of Education and Culture Republic Indonesia for supporting this study.

\section{REFERENCES}

[1] M.M. Conroy and P.R. Berke, What makes a good sustainable development plan? An analysis of factors that influence principles of sustainable development. Environment and planning A, 36(8), 2004, 1381-1396.

[2] P. Lawn, Sustainable Development Indicators in Ecological Economics.(Edward Elgar Publishing Limited Glensande Home Montpellier Parade Cheltenham Glos GL. 501 UA. UK, 2006).

[3] F. Fukuyama, Social capital, civil society and development. Third world quarterly, 22(1), 2001, 7-20.

[4] D.S. Sasradipoera, and D. Hantono Strategies for developing Lahendong geothermal field, Indonesia. Proceedings of Twenty-Eighth Workshop on Geothermal Reservoir Engineering, Stanford University, 2003, 27-29.

[5] R. Bertani, World geothermal power generation in the period 2001-2005.Geothermics, 34(6), 2005, 651-690.

[6] S. Hariyadi, B. Polii, and B. Yanuwiadi, Feasibility Analysis of Geothermal Power Plant Wastewater Utilization: A Case Study on Lahendong Geothermal Power Plant, North Sulawesi. International Journal of Basic and Applied Science 12(6), 2012,187-190.

[7] K. Bäckstrand, Multi-stakeholder partnerships for sustainable development: rethinking legitimacy, accountability and effectiveness. European Environment, 16(5), 2006, 290-306.

[8] R. Ramirez, Stakeholder analysis and conflict management. Cultivating peace: conflict and collaboration in natural resource management, 1999, 101-126.

[9] PT PGEA Lahendong, Geothermal Enegry Development, Lahendong, North Sulawesi. PT Pertamina, Tomohon, North Sulawesi, 2012 .

[10] G. Mansuri and V. Rao, Community-based and-driven development: A critical review. The World Bank Research Observer, 19(1), 2004, 1-39.

[11] M. Minniti, The role of government policy on entrepreneurial activity: productive, unproductive, or destructive?. Entrepreneurship Theory and Practice, 32(5), 2008, 779-790.

[12] G. Ritzer and B. Smart, Handbook of Social Theory, Sage Publication. London, 2001.

[13] A.O. Krueger, The Political Economy of The Rent Seeking Society. The American Economic Review 574 (64) No. 3.1974.

[14] G. Mohan and K. Stokke, Participatory development and empowerment: the dangers of localism. Third world quarterly, 21(2), 2000, 247-268.

[15] R.A. Noe, Employee training and development. Boston: McGraw-Hill/Irwin, 2002.

[16] E.C. Jr. Pasour, The Free Rider as a Basis for Government Intervention. The Journal of Libertarian Studies, 5(4), 1981.

[17] E. Ostrom, R. Gardner and J. Waker, Rules, Games, and Common-Poll Resources. Ann Arbor, MI: University of Michigan Press, 1994.

[18] E. Ostrom, Institutional Rational Choice: An Assessment of the Institutional Analysis and Development Framework. In P.A. Sabatier (Ed.), Theories of the policy process, Boulder, CO: West view Press, 2007.

[19] T. Parsons, Acton, Situation, and Normative Pattern. Publish by Lidz \& Staubmann, German 2004.

[20] C.E. Rusbult and P.A. Van Lange, Interdependence, interaction, and relationships. Annual review of psychology, 54(1), 2003, 351375 . 